\title{
Antinociceptive and Anti-inflammatory Effects of Combined Administration of $\alpha$-Tocopherol and Morphine in Acetic Acid Induced Writhing Test
}

\author{
*Dr. T Habib ${ }^{1}, \mathrm{~S} \mathrm{Begum}^{2}, \mathrm{~T}^{\mathrm{Ali}}{ }^{3}, \mathrm{M} \mathrm{Imtiaz}^{4}, \mathrm{~S}_{\text {Masood }^{5}}$ \\ $1 *$ Tamanna Habib, Assistant Professor, Department of Physiology \\ Anwer Khan Modern Medical College, Dhaka \\ ${ }^{2}$ Prof. Dr. Shelina Begum, Professor and Chairman, Department of Physiology \\ Bangabandhu Sheikh Mujib Medical University (BSMMU), Dhaka \\ ${ }^{3}$ Dr. Taskina Ali, Associate Professor, Department of Physiology \\ Bangabandhu Sheikh Mujib Medical University (BSMMU), Dhaka \\ ${ }^{4}$ Dr. Masud Imtiaz, Assistant Professor, Department of Physiology \\ Ad-din Sakina Medical College, Jessore \\ ${ }^{5}$ Dr. Shahriar Masood, Assistant Professor, Department of Physiology \\ Jahurul Islam Medical College, Bajitpur \\ *Corresponding author
}

Date of submission: 08 May 2016

Date of acceptance: 15 June 2016

\begin{abstract}
Background: Morphine represents the front line therapy for the clinical management of acute and chronic pain but has a number of side effects. So, to minimize the side effect of this tradition analgesic, this study is aimed to explore that combination of morphine and $\alpha$-tocopherol $(\alpha \mathrm{T})$ are better analgesic as well as anti-inflammatory effect than that of morphine alone.

Objective: to assess the effects of combination of morphine with $\alpha$-tocopherol against nociceptive and inflammatory pain.

Methods: This prospective experimental study was conducted in the Department of Physiology, Bangabandhu Sheikh Mujib Medical University (BSMMU), Shahbag, Dhaka from January 2013 to December 2013. For this purpose, 15 male Long Evans rats were studied. On the basis of vitamin and drug administrations, the rats were divided into three (3) groups (5 rats in each). Control group received normal saline, one experimental group received morphine sulphate (MS) at a dose of $3 \mathrm{mg} / \mathrm{kg}$ body weight and another experimental group received combination of DS with $\alpha \mathrm{T}$ at a dose of $3 \mathrm{mg} / \mathrm{kg}$ body weight and $500 \mathrm{mg} / \mathrm{kg}$ body weight, respectively. All the groups received single dose and equal volume $(1 \mathrm{ml})$ through intraperitoneal route 1 hour before the test. Just one hour after administrations, they were subjected to acetic acid induced writhing test . The data were statistically analyzed by ANOVA followed by Bonferroni Post Hoc test.
\end{abstract}

Results: combined administration of MS and $\alpha \mathrm{T}$ significantly lowered $(\mathrm{p} \leq 0.05)$ the variables for visceral nociceptive pain and inflammatory pain than individual administration of MS. Conclusion: from this study it may be concluded that combined administration of morphine sulphate and $\alpha$-tocopherol were more effective in lowering the nociceptive and inflammatory pain than individual administration of morphine.

Key Words: Analgesic, inflammatory pain, morphine, nociceptive pain, $\alpha$-tocopherol, writhing test

\section{Introduction}

Pain is the sensation of acute physical hurt or discomfort caused by injury or illness. It is an unpleasant sensation that is conveyed to the brain by sensory neuron. Its purpose is chiefly protective; it acts as warning that the tissues are being damaged and induces the sufferer to remove or withdraw from the source ${ }^{1}$. Its discomfort

brings the patient to physicians. The nociceptive pain is an expected physiological response to any noxious chemical, thermal or mechanical stimulus ${ }^{2}$. The visceral nociceptive pain is characterized by poor localization, strong emotional response, immobility coupled with tonic increases in muscle tone ${ }^{3}$. The inflammatory pain is 
Antinociceptive and Anti-inflammatory Effects of Combined Administration generated by activation and sensitization of the nociceptive pathway by inflammation as well as noxious stimulation $^{4-5}$. But if the tissue damage occurs even after the nociceptive withdrawal response, then the healing process starts through inflammation ${ }^{6}$. Inflammation is fundamentally a protective response. Inflammation is the body's natural response to injury. It is a multi-mediated phenomenon in which all mediators would come \& go at the appropriate moment, increasing vascular permeability, attracting leukocyte, producing pain, local edema and necrosis 7 .

Opioids have been the main drugs used in the management of pain for several decades. But repeated use of opioids such as morphine causes analgesic tolerance, physical dependence and opioid addiction. The opioid receptors are normally stimulated by endogenous peptides which are produced in response to noxious stimulation 8 . Different investigators of different countries have experimented that morphine has visceral anti nociceptive and anti inflammatory effect in acetic acid induced writhing test ${ }^{9-11}$. $\alpha \mathrm{T}$ is a primary membrane bound, lipid soluble, chain breaking antioxidant ${ }^{11}$ among the eight different types of vitamin E. Recently, the analgesic and anti-inflammatory effects of $\alpha \mathrm{T}$ have been demonstrated in different experimental animals ${ }^{12-14}$. In this present study, the centrally acting analgesic morphine is used in combination with ?T with the aim to maximize the therapeutic efficacy while minimizing the side effct. Till now in Bangladesh no experiment has been done regarding the antinociceptive and anti-inflammatory effect of combination of morphine sulphate and $\alpha$-tocopherol as a single loading dose and compare these effect with individual administration of morphine in acetic acid induced writhing test.

\section{Materials and Methods}

This prospective experimental study was conducted in the Department of Physiology, Bangabandhu Sheikh Mujib Medical University (BSMMU), Shahbag, Dhaka from 1st January 2013 to $31^{\text {st }}$ December 2013. All the experiments were conducted according to the guidelines for the Animal Experimentation Ethics Committee, Institute of Cholera and Diarrhoeal Disease Research, Bangladesh (icddr, b; 2003) and was approved by the Ethical review board (IRB), BSMMU.

\section{Experimental animal}

For this study, fifteen(15) male long Evans rats, weighting about 180-250 gram were obtained from animal house of Bangladesh Institute of Research and
Rehabilitation for Diabetic Endocrine and Metabolic Disorders (BIRDEM), Shahbag, Dhaka. They were kept under a $12 / 12$ hour light/dark cycle ${ }^{15}$. The room temperature was kept at $28^{\circ} \mathrm{C} \pm 50 \mathrm{C}$ which was corresponded to the thermo-neutral zone of rats ${ }^{16}$ at the Pain laboratory of the Department of Physiology, BSMMU. All the animals were there for consecutive 7 days prior to the experiments for acclimatization and had free access to standard laboratory food and boiled water after cooling. All the experiments were performed during the day time between 8:00 AM to 1:00 PM, to avoid the circadian influences.

\section{Grouping}

On the basis of vitamin and drug administrations, the rats were divided into three (3) groups (5 rats in each). Control group received normal saline, one experimental group received morphine sulphate (MS) at a dose of 3 $\mathrm{mg} / \mathrm{kg}$ body weight and another experimental group received combination of DS with $\alpha \mathrm{T}$ at a dose of $3 \mathrm{mg} / \mathrm{kg}$ body weight and $500 \mathrm{mg} / \mathrm{kg}$ body weight, respectively. All the groups received single dose and equal volume (1 $\mathrm{ml}$ ) through intraperitoneal route 1 hour before the test. Just one hour after administrations, they were subjected to acetic acid induced writhing test.

\section{Writhing test}

On the day of experiment, the rat was adminstrated by NS or MS or combined dose of MS and $\alpha \mathrm{T}$ intraperitonealy. One hour after administration, $1 \mathrm{ml}$ of $2 \%$ acetic acid was injected intraperitoneally using a insulin syringe. Immediately after the injection, the latency time and the number of writhes were counted upto 60 minutes of observation period. Finally $\%$ analgesic activity was calculated by using following formula ${ }^{16}$.

\section{Latency time}

Period between the administration of acetic acid and the beginning of the first writh.

\section{Writhing}

Contraction of the abdominal masculature followed by extension of the hind limbs.

The results were expressed as mean $\pm \mathrm{SE}$ and the data were statistically analyzed by ANOVA followed by Bonferroni's Post Hoc test. In the interpretation of results $\mathrm{p} \leq 0.05$ was accepted, as the level of significant. 


\section{Results}

The effects of intraperitoneal (i.p) administration of MS and its combination with $\pm T$ in the writhing test were observed. In this test, the latency time and percentage of analgesic activity were analyzed as nociceptive pain behavior and the total number of writhes were analyzed as inflammatory pain behavior.

\section{Nociceptive pain}

In the writhing test, All the mean values of this variable were significantly $(p \leq 0.001)$ lowered in the study groups in comparison to that of control group. This variable was significantly $(\mathrm{P} \leq 0.01)$ lowered in the combined administered group in comparison to morphine administered group (Table: 1) (Figure: 1)

Table : 1

\begin{tabular}{cccc}
\hline GROUPS & $\mathbf{n}$ & $\begin{array}{c}\text { Latency Time } \\
\text { in minutes }\end{array}$ & $\begin{array}{c}\text { \% of } \\
\text { analgesic } \\
\text { active }\end{array}$ \\
\hline Control & 5 & $\begin{array}{c}5.5 \pm 0.63 \\
(4 \text { to } 7)\end{array}$ & 0 \\
MS & 5 & $\begin{array}{c}13.4 \pm 0.51 \\
(11.5 \text { to } 14.5)\end{array}$ & 68.88 \\
MS+T & 5 & $\begin{array}{c}17.8 \pm 0.87 \\
(16 \text { to } 21)\end{array}$ & 73.26 \\
\hline
\end{tabular}

Table : 2

\begin{tabular}{ccc}
\hline Group & $\mathbf{n}$ & \multicolumn{1}{c}{$\begin{array}{c}\text { Number of writhes } \\
\text { (Frequency/ 60 min) }\end{array}$} \\
\hline Control & 5 & $\begin{array}{l}71.8 \pm 2.92 \\
(67 \text { to } 83)\end{array}$ \\
MS & 5 & $\begin{array}{l}23.2 \pm 1.07 \\
(21 \text { to } 27) \\
19.2 \pm 0.86 \\
\text { MS+T }\end{array}$ \\
& 5 & $(17$ to 22$)$ \\
\end{tabular}
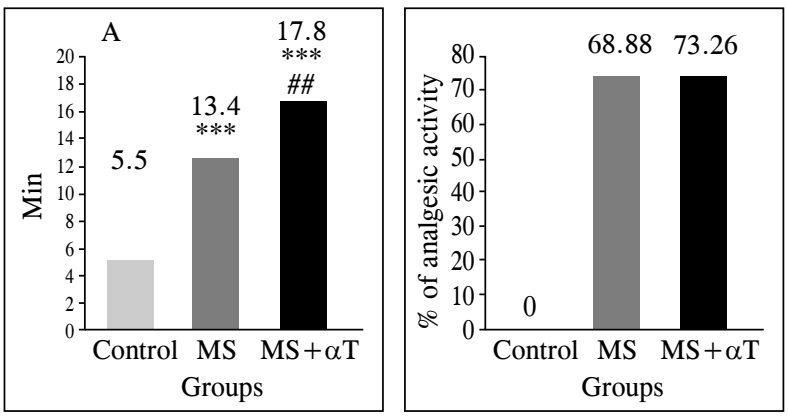

Figure 1: The latency time (A) and \% of analgesic activity (B) of writhing test in different groups of rats. Each bar symbolizes for mean \pm SE for 5 rats. $* * *=\mathrm{p}_{\leq} 0.001$, compared to control and $\# \#=\mathrm{p} \leq 0.01$, compared between MS vs MS $+ \pm \mathrm{T}$
Inflammatory pain

Again, the number of writhes in writhing test was significantly $(p \leq 0.001)$ lowered in the study groups in comparison to the control group. Moreover, this study variable was lowered in the combined administered group than that of morphine administered group and it was statistically $(\mathrm{p} \leq 0.01)$ significant (Table: 2$)$ (figure:2)

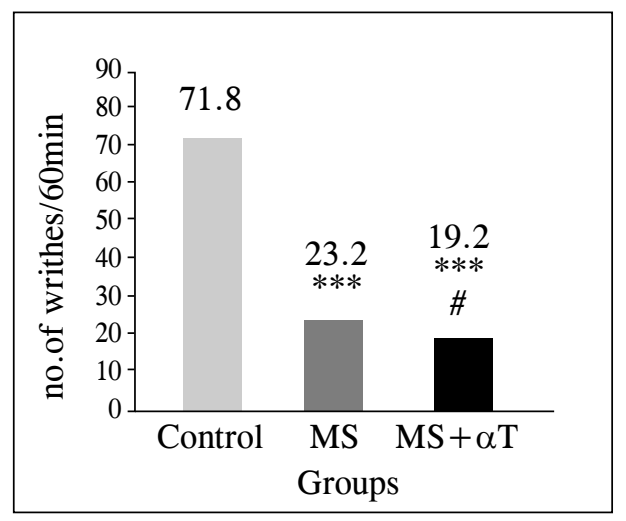

Figure 2: Number of writhes in writhing test in different groups of rats. Each bar symbolizes for mean \pm SE for 5 rats. $* * *=p \leq 0.001$, compared to control and \# $=\mathrm{p} \leq 0.05$, compared between MS vs MS $+ \pm \mathrm{T}$

\section{Discussion}

Pain is the most common reason for medical consultation ${ }^{17}$ as it is not a simple process and in many instances it continues to produce severe distress that disrupted the quality of life. In our body, there are several compensatory mechanisms for inhibiting the initiation of pain and block the pathway of pain transmission. In addition to this, there are lots of analgesic to treat the pain but they have a number of side effects. So, Search for newer drugs with fewer side effects for treating pains is a very important issue of research now a days. From this point the present study was undertaken to assess the analgesic and anti inflammatory effect of combination of traditional analgesic morphine with $\alpha$-tocopherol and compare these effects with the individual administration of morphine.

The acetic acid induced writhing is a standard test for screening of visceral nociceptive and inflammatory pain. It is an overt response to the pain produced by irritant subdtance. This test is sensitive to opiates as well as non opiate analgesics. In writhing test, the signal is transmitted to the CNS in response to pain due to irritation and release of endogenous mediators like 


\section{Results}

The effects of intraperitoneal (i.p) administration of MS and its combination with $\pm T$ in the writhing test were observed. In this test, the latency time and percentage of analgesic activity were analyzed as nociceptive pain behavior and the total number of writhes were analyzed as inflammatory pain behavior.

\section{Nociceptive pain}

In the writhing test, All the mean values of this variable were significantly $(p \leq 0.001)$ lowered in the study groups in comparison to that of control group. This variable was significantly $(\mathrm{P} \leq 0.01)$ lowered in the combined administered group in comparison to morphine administered group (Table: 1) (Figure: 1)

Table : 1

\begin{tabular}{cccc}
\hline GROUPS & $\mathbf{n}$ & $\begin{array}{c}\text { Latency Time } \\
\text { in minutes }\end{array}$ & $\begin{array}{c}\text { \% of } \\
\text { analgesic } \\
\text { active }\end{array}$ \\
\hline Control & 5 & $\begin{array}{c}5.5 \pm 0.63 \\
(4 \text { to } 7)\end{array}$ & 0 \\
MS & 5 & $\begin{array}{c}13.4 \pm 0.51 \\
(11.5 \text { to } 14.5)\end{array}$ & 68.88 \\
MS+T & 5 & $\begin{array}{c}17.8 \pm 0.87 \\
(16 \text { to } 21)\end{array}$ & 73.26 \\
\hline
\end{tabular}

Table : 2

\begin{tabular}{ccc}
\hline Group & $\mathbf{n}$ & \multicolumn{1}{c}{$\begin{array}{c}\text { Number of writhes } \\
\text { (Frequency/ 60 min) }\end{array}$} \\
\hline Control & 5 & $\begin{array}{l}71.8 \pm 2.92 \\
(67 \text { to } 83)\end{array}$ \\
MS & 5 & $\begin{array}{l}23.2 \pm 1.07 \\
(21 \text { to } 27) \\
19.2 \pm 0.86 \\
\text { MS+T }\end{array}$ \\
& 5 & $(17$ to 22$)$ \\
\end{tabular}
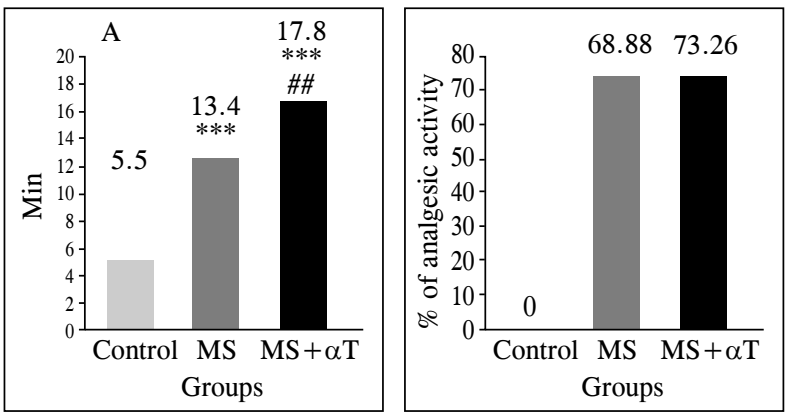

Figure 1: The latency time (A) and \% of analgesic activity (B) of writhing test in different groups of rats. Each bar symbolizes for mean \pm SE for 5 rats. $* * *=\mathrm{p}_{\leq} 0.001$, compared to control and $\# \#=\mathrm{p} \leq 0.01$, compared between MS vs MS $+ \pm \mathrm{T}$
Inflammatory pain

Again, the number of writhes in writhing test was significantly $(p \leq 0.001)$ lowered in the study groups in comparison to the control group. Moreover, this study variable was lowered in the combined administered group than that of morphine administered group and it was statistically $(\mathrm{p} \leq 0.01)$ significant (Table: 2$)$ (figure:2)

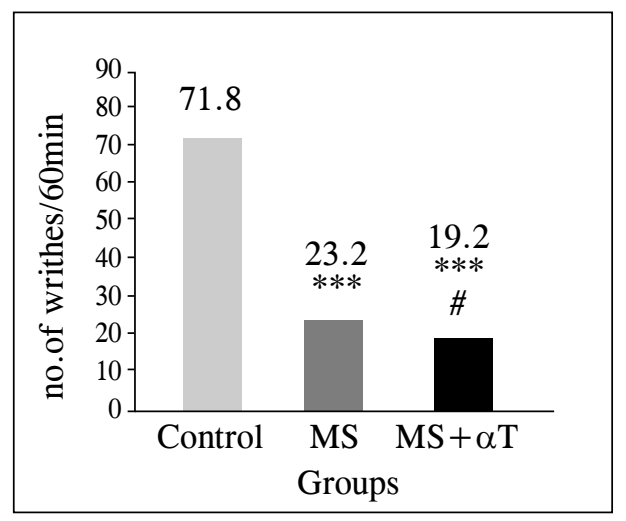

Figure 2: Number of writhes in writhing test in different groups of rats. Each bar symbolizes for mean \pm SE for 5 rats. $* * *=p \leq 0.001$, compared to control and \# $=\mathrm{p} \leq 0.05$, compared between MS vs MS $+ \pm \mathrm{T}$

\section{Discussion}

Pain is the most common reason for medical consultation ${ }^{17}$ as it is not a simple process and in many instances it continues to produce severe distress that disrupted the quality of life. In our body, there are several compensatory mechanisms for inhibiting the initiation of pain and block the pathway of pain transmission. In addition to this, there are lots of analgesic to treat the pain but they have a number of side effects. So, Search for newer drugs with fewer side effects for treating pains is a very important issue of research now a days. From this point the present study was undertaken to assess the analgesic and anti inflammatory effect of combination of traditional analgesic morphine with $\alpha$-tocopherol and compare these effects with the individual administration of morphine.

The acetic acid induced writhing is a standard test for screening of visceral nociceptive and inflammatory pain. It is an overt response to the pain produced by irritant subdtance. This test is sensitive to opiates as well as non opiate analgesics. In writhing test, the signal is transmitted to the CNS in response to pain due to irritation and release of endogenous mediators like 
Antinociceptive and Anti-inflammatory Effects of Combined Administration bradykinin and Prostaglandin which contributes to increase sensitivity to receptors ${ }^{15}$. In our present study the combined administration of morphine and vitamin significantly $(\mathrm{p} \leq 0.05)$ lowered all the variables for nociceptive and inflammatory pain than single administration of morphine. Though the exact mechanisms of these effects could not be elucidated from this study, but several investigators of different countries suggested different mechanisms for the decrement of nociceptive pain. ?-tocopherol may reduce the nociceptive pain by enhancing the activity of GABA in the CNS which causes the inhibition of central nociceptors ${ }^{18-19}$. On the other hand, morphine may activates the serotonergic pathway and release of endogenous opioids like enkephaklin and ultimately inhibits the activation of nociceptors or by inhibiting the opening of voltage gated calcium channel ${ }^{20-22}$.

Several investigators of different countries observed that, ?-tocopherol has reduced the inflammatory pain by by lowering serum $\mathrm{PGE}_{2}$ by inhibiting phospholipase $\mathrm{A}_{2}$ as well as $\mathrm{COX}-2$, decrement of production of NO, TNF- $\alpha$, free radicals $23-25$. Morphine may reduce inflammation and inflammatory pain by inhibiting the nociceptors directly in the inflamed $\operatorname{skin}^{26}$ or may reduces the level of $\mathrm{PGE}_{2}$ and bradykinin $^{27}$ or by opioid peptides secreted by immune cells can activate opioid receptors on sensory nerve terminals to inhibit nociception ${ }^{28}$.

Though the exact mechanism of these more effectiveness of the combined administration could not be elucidated directly from this study, however, the concomitant activation of different pain lowering pathways at the same time might be the possible cause.

\section{Conclusion}

Therefore, from this result, it may be concluded that combination of morphine sulphate and $\pm \mathrm{T}$ reduced nociceptive and inflammatory pain more effectively, than individual administration of morphine sulphate. This study will apprise the clinician and general population about the beneficial use aT along with MS for better management of pain.

Conflict of interest: absent

\section{References}

1. Abott FA, Fraser MI. Use and abuse of over-thecounter analgesic agents. J Psychiatry Neurosci.1998; 23(1): 13-34.

2. Carr DB, Goudas LC. Acute pain.1999; 353: 20512058

3. Ness T.J. Models of visceral nociception. ILAR J. 1999; 40(3): 119-128

4. Eli I, Svensson P.The multi-dimensional nature of pain. In: Bergenholtz G; Hostewd-Bindslev P, Reit C, editors. Textbook of endontology. 2nd ed. New Jersey: Wiley-Blackwell.2009; p277-289

5. Woolf CJ. Pain: moving from symptom control toward mechanism-specific pharmacologic management. Ann Intern Med. 2004; 140: 441-451.

6. Walter JB, Talbot IC. Walter and Israel General Pathology. 7th ed. Edinburgh: Churchill Livingstone.1996; p118

7. Loeser JD, Treede RD. The Kyoto protocol of IASP Basic Pain Terminology. Pain. 2008; 137(3): 473-477.

8. Trescot AM, Datta S, Lee M, Hanseen H. Opioid Pharmacology. Pain Physician. 2008; 11:133-153.

9. Meert TF, Galantine EL. A comparision of the anti nociceptive and adverse effects of mu opioid agonist Morphine and the delta opioid receptor agonist SN C80. Basic and clinical Pharmacology and toxicology. 2005; 39-51.

10. Tamaddonford E, Hamzah F, Hamzah N. Effect of curcumin on morphine induced antinociception in acute corneal pain in rats. International $\mathrm{J}$ of vatirinary research. 2015; 2:127-131

11. Miranda HF, Aranda N, Prieto-Rayo JC, Noringa V, Zanelta P, Sierralta F. Isobolographic analysis of the opioid- op[ioid interaction in a tonic and a phasic mouse model of induced nociceptive pain. $\mathrm{J}$ of Biomedical Sci.2014; 21: 62-70

12. Lazzarini M, Salum C, Delbel EA. Combined treatment of ascorbic acid or alpha tocopherol with receptors antagonist or nitric oxide synthase inhibitor potentiates cataleptic effect in mice. Psychopharmacol.2005; 181: 71-79.

13. Lu R, Gerhardt WK, Geisslinger G, Schmidtko A. Additive anti nociceptive effects of a combination of vitamin $\mathrm{C}$ and vitamin $\mathrm{E}$ after peripheral nerve injury. Research article.2011; 6(12): 1-5. 
14. Emamgoreshi F, Owji SM, Motamedifar M. Evaluation of effectiveness of vitamin $\mathrm{C}$ and $\mathrm{E}$ on prevention of renal scar due to pylonephritis in Rats. Advanced in Urology.2011:1-6.

15. Tajik H,Tamaddonfard E, Hamzah N. The effect of curcumin on the acetic acid induced visceral nociception in rats. Pak J Biol scei.2008; 11(2): 312-314.

16. Uddin Z, Aninda KN, Anowara J, Mycal D, Masud MM, Talha BE. Analgesic activities of Crinum asiaticum. Mol and Clinc Pharmacol.2012; 3(2): 125-133.

17. Basbaum A, Bushnell MC, Devor M. Pain: Basic mechanisms. In: Justins DM, editor. Pain. An updated Review: refresher course syllabus. Seattle: IASP press.2005; p 3-9.

18. Nadine C, Ferreira MC, Solal CC, Kadmi CM, Bernad N, Martinez J, et al. ?-tocopherol and ?tocopheryl phosphate interact with the canabinoid system in the rodent hippocampus. Free Radic Bio Med. 2011;51: 1643-1655.

19. Barrett KE, Barman SM, Boitano S, Brooks H. Ganong's Review of Medical Physiology. 23rd ed. New Delhi:Tata McGraw- Hill. 2010; p167-168.

20. Chahl LA. Opioids- mechenism of action. Ex and clin pharmacol. 1996; 9: 63-65
21. Stamford JA.Descending control of pain. $\mathrm{Br} \mathrm{J}$ Anesth. 1995; 75: 217-227.

22. Dafny N. Pain Modulation and mechenisms. Mol pain. 2000; 38(5): 172-178.

23. Alorainy M. Effect of allopurinol and vitamin $\mathrm{E}$ on rat model of rheumatoid arthritis. Int $\mathbf{J}$ health Sci. 2008; 2(1): 59-67.

24. Jensen SK, Lauridsen C. Alpha tocopherol sterioisomers. Vitam Horm. 2007; 6: 281-308.

25. Kumar V, Abbas AK, Fausto N, Aster JC. Robbins and Cotran Pathologic Basis of Disease. 8th ed. India: Elson morpevier Saunders.2010; p95-160.

26. Wenk HN, Brederson JD, Honda CN. Morphine directly inhibits the nociceptors in the inflamed skin. J Neurophysiol.2006; 95(4): 2083-2097.

27. Vanloon JP, Degrew JC, Van DM, Lami JJ, Vanweeren PR. Intra articular opioid analgesia is effective in reducing pain and inflammation in an equine LPS induced synovitis model. Equine Vet J. 2010; 42(5): 412-419.

28. Brunton LL, Lazo JS, Parker KL. Goodman and Gilman's-The pharmacological basis of therapeutics. 11th ed. Mcgraw-hill medical publishing division. 2011; 553-558. 